\title{
Stochastic finite-fault modeling of ground motions from the June 27, 1998 Adana-Ceyhan earthquake
}

\author{
Esref Yalcinkaya \\ Istanbul University, Engineering Faculty, Geophysical Engineering, 34320 Avcilar, Istanbul, Turkey
}

(Received July 22, 2004; Revised January 17, 2005; Accepted January 19, 2005)

\begin{abstract}
In this study, acceleration time histories of the June 27, 1998 Adana-Ceyhan (Turkey) earthquake, are simulated using a stochastic modeling technique for finite faults proposed by Beresnev and Atkinson (1997). The fault length, width and the depth to the top of the fault for the earthquake are assumed $30 \mathrm{~km}, 21 \mathrm{~km}$ and $15 \mathrm{~km}$, respectively, based on the aftershock distribution. Simulations are made for two common site classes: soil and rock. Their response characteristics are obtained from the site-specific amplification functions estimated for the weak motion seismograms at stations located in the region using spectral ratio methods. The results show that the overall agreement between simulated and observed waveforms and spectra is quite satisfying. However, significant discrepancies exist at certain stations, implying that site amplification functions play an important role in the simulation process. The effects of nonlinearity and basin edge generated surface waves do not clearly dominate on the results. The peak horizontal acceleration contours estimated using the calibrated model are consistent with the observed intensity values and the other evidences of strong ground motions.
\end{abstract}

Key words: Adana-Ceyhan, lower crust, stochastic finite-fault modeling, site responce.

\section{Introduction}

The prediction of earthquake ground motions for large earthquakes is a crucial problem in engineering seismology. Engineering analysis for seismic performance of structures require seismological input that describes the amplitude, frequency content, and duration of the expected ground motions. Stochastic modeling of earthquake radiation is widely used in prediction of strong ground motions (e.g. Hanks and McGuire, 1981; Boore, 1983, 1996; Boore and Atkinson, 1987; Atkinson and Boore, 1997; Toro et al., 1997). In this method, high-frequency earthquake motions are represented as band-limited Gaussian noise having a $\omega^{2}$ mean spectrum. In the most commonly employed approach, earthquakes are treated as point sources, thus not taking into account the finite-fault effects such as rupture geometry and directivity. To accommodate these effects, several authors have recently extended the stochastic modeling technique to consider rupture along a finite-fault plane (e.g. Beresnev and Atkinson, 1997; Kamae and Irikura, 1992).

In this study, the stochastic finite-fault modeling technique developed by Beresnev and Atkinson (1997) is used to model the ground motions from the June 27, 1998, Adana-Ceyhan earthquake $\left(\mathrm{M}_{S}=6.2 \mathrm{USGS}, \mathrm{M}_{L}=5.9 \mathrm{ERD}\right.$ : Turkish Earthquake Research Department). The ERD estimated that the epicenter of the mainshock was located about $30 \mathrm{~km}$ southeast of Adana and $32 \mathrm{~km}$ away from the center of Ceyhan town, as shown in Fig. 1. Adana is the fourth largest city and one of the most important industrialized and agricultural centers of Turkey. The earthquake

Copy right(c) The Society of Geomagnetism and Earth, Planetary and Space Sciences (SGEPSS); The Seismological Society of Japan; The Volcanological Society of Japan; The Geodetic Society of Japan; The Japanese Society for Planetary Sciences; TERRAPUB. caused unexpectedly intensive damage to old and modern reinforced concrete multistory buildings. 145 people were killed, 1500 were injured and many thousands were made homeless. Estimated economic loss is about one billion US dollars (Adalier and Aydingun, 2001). The AdanaCeyhan area is located in the Eastern Mediterranean region of Turkey and includes complex tectonic features such as a triple junction consisting of the East Anatolian Fault, the Dead Sea Fault, and Cyprus Arc fault systems (Fig. 1). The region is dominated by a number of NE-SW trending strike-slip faults. The main tectonic structures are the Kozan Fault, the Yumurtalık Fault, and the Goksun Fault Zone, all three lying mainly in the NE-SW direction (Kozlu, 1987). Being on a tectonically active zone, the AdanaCeyhan region had experienced similar destructive earthquakes in $1945\left(\mathrm{M}_{S}=6.5\right)$ and $1952\left(\mathrm{M}_{S}=5.6\right)$ (Adalier and Aydingun, 2000).

The Adana-Ceyhan earthquake did not yield a surface rupture, however, the earthquake was related with the Misis-Ceyhan fault by Barka et al. (1998), the Goksun Fault Zone by Aktar et al. (2000) and an unmapped fault by Utkucu et al. (2001), all of them characterized by left-lateral strike-slip movements. The depth $(32 \mathrm{~km})$ and magnitude of the mainshock, and the distribution of aftershocks indicate that the rupture nucleated within the lower crust, and did not extend to shallower zones (Aktar et al., 2000). The stations at similar epicentral distances recorded very different peak accelerations depending on local site condition and rupture directivity. Site response analyses based on spectral ratios revealed that soil behavior was one of the most significant factors in the damage to buildings caused by the earthquake (Celebi, 2000; Yalcinkaya and Alptekin, 2005a). Simulation of ground motions using a stochastic finite-fault model- 


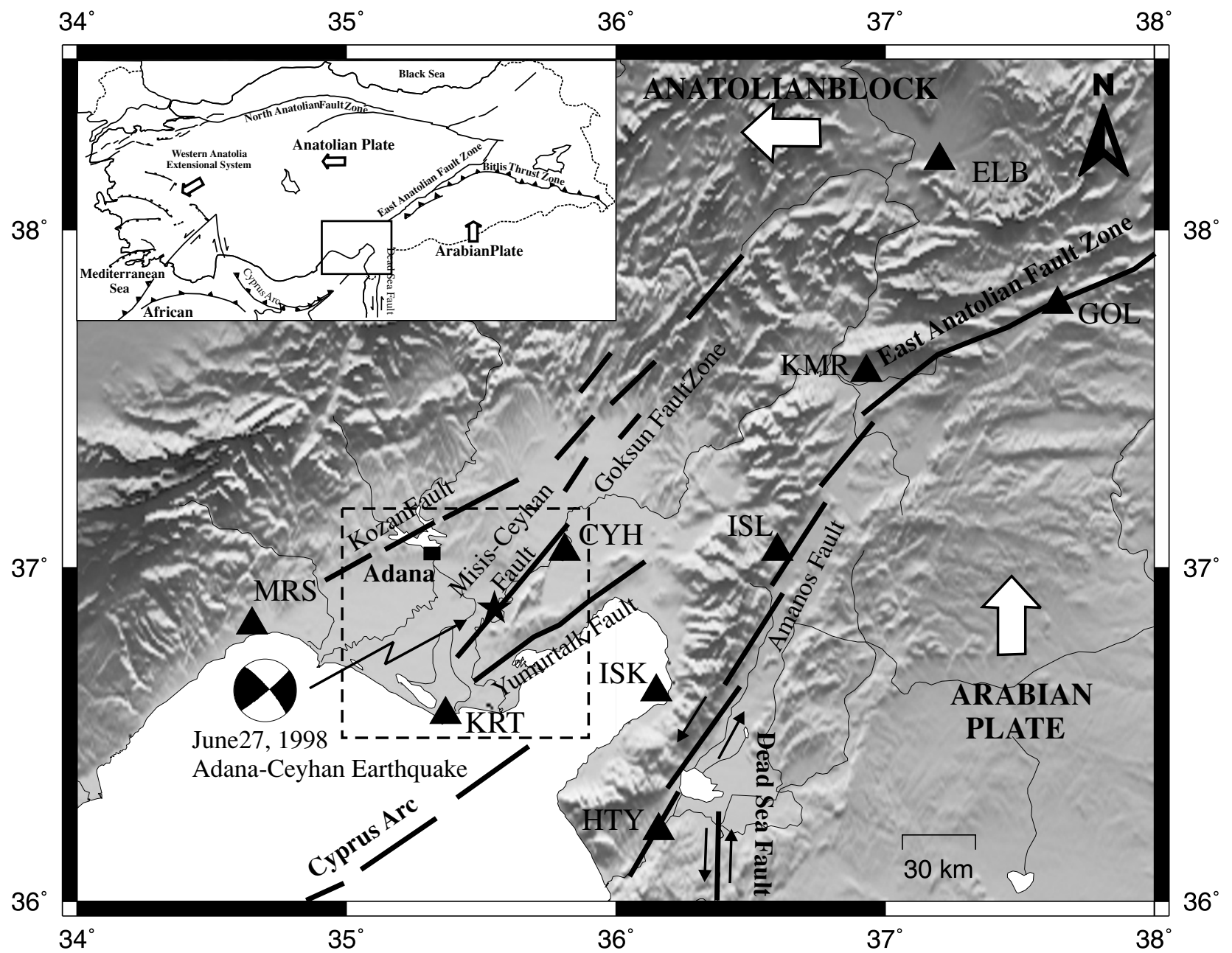

Fig. 1. Tectonic map of the study area, showing the locations of the stations which recorded the mainshock (black triangles). The dashed square indicates the area in Fig. 2.

ing technique will help to better understand this earthquake and its effects on structures and buildings.

\section{Data Description}

The Adana-Ceyhan earthquake was recorded at nine strong motion stations, operated by the ERD, which have the epicentral distances ranging from $32 \mathrm{~km}$ to $212 \mathrm{~km}$. Information for all stations is given in Table 1 and their locations are shown in Fig. 1. The recording instruments consist of four analog (SMA-1) and five digital accelerographs (SM-2, GSR-18). The sample intervals of the records change as 0.01 and $0.005 \mathrm{~s}$. All data used in this study were band-pass filtered $(0.25-25 \mathrm{~Hz})$ using fourth order Butterworth filter after the baseline correction. Unfortunately, a detailed site classification was not available for most of the recording stations. For that reason, two general site classes for the stations; rock and soil were adopted. The classification is based on the surface geology reported by the ERD. The assumed rock and soil classes may match with soft rock or stiff soil and soft soil, respectively, as proposed by Boore et al. (1993); that is, $360<V_{\mathrm{S} 30}<750 \mathrm{~m} / \mathrm{s}$ for soft rock or stiff soil, and $180<V_{\mathrm{S} 30}<360 \mathrm{~m} / \mathrm{s}$ for soft soil $\left(V_{\mathrm{S} 30}\right.$ : shear wave velocity averaged over the top $30 \mathrm{~m}$ ). The horizontal components of time domain signals are shown in Fig. 4. While the digital stations (CYH, HTY, $\mathrm{KMR}, \mathrm{GOL}$ ) recorded all phases, recordings at the analogue stations (ISK, KRT, ISL, MRS) consisted of only S waves, because of the instrumental specifications. At the ELB digital station, the seismogram recording was terminated too early.

\section{Method and Modeling Parameters}

Waveforms at all stations were simulated using the computer program FINSIM (Beresnev and Atkinson, 1998a) which combines the stochastic ground motion modeling technique with the kinematic model of rupture propagation. The parameters of the finite fault simulation method include the fault geometry, regional properties describing the path effect, subfault size, and radiation strength factor (related to maximum slip velocity). In this method, the finite source is represented by a rectangular fault plane, which is subdivided into a number of subfaults. Each one is treated as a point source and the center of subfault is selected as the location of the hypocenter. The rupture starts at the hypocenter and propagates radially from it, triggering the adjacent subfaults when it reaches its center. The subfault acceleration time history is propagated to the observation point through empirical distance-dependent duration, geometric 
Table 1. Parameters of recording stations and peak horizontal acceleration values (PHA) of observed horizontal components (NS, EW) and those of simulated random horizontal component (Sim).

\begin{tabular}{|c|c|c|c|c|c|c|c|}
\hline \multirow[t]{2}{*}{ Station } & \multirow{2}{*}{$\begin{array}{c}\text { Latitude } \\
\left({ }^{\circ} \mathrm{N}\right)\end{array}$} & \multirow{2}{*}{$\begin{array}{l}\text { Longitude } \\
\qquad\left({ }^{\circ} \mathrm{E}\right)\end{array}$} & \multirow{2}{*}{$\begin{array}{c}\text { Epicentral } \\
\text { distance }(\mathrm{km})\end{array}$} & \multicolumn{3}{|c|}{$\mathrm{PHA}^{*}\left(\mathrm{~cm} / \mathrm{s}^{2}\right)$} & \multirow[t]{2}{*}{ Site class } \\
\hline & & & & NS & EW & Sim. & \\
\hline Ceyhan (CYH) & 37.05 & 35.81 & 32 & 226.3 & 290.4 & 240.2 & Soil \\
\hline Karatas (KRT) & 36.561 & 35.367 & 36 & 24.9 & 33.6 & 36.8 & Rock \\
\hline Iskenderun (ISK) & 36.63 & 36.15 & 60 & 16.2 & 14.2 & 58.9 & Soil \\
\hline Mersin (MRS) & 36.83 & 34.65 & 80 & 133.2 & 114.9 & 21.5 & Soil \\
\hline Islahiye (ISL) & 37.05 & 36.6 & 85 & 17.8 & 18.7 & 19.7 & Rock \\
\hline Hatay (HTY) & 36.213 & 36.16 & 90 & 28.9 & 24.4 & 32.1 & Soil \\
\hline Kahramanmaras (KMR) & 37.58 & 36.931 & 147 & 6.7 & 6.6 & 12.8 & Soil \\
\hline Golbası (GOL) & 37.781 & 37.641 & 209 & 4.1 & 2.8 & 4.9 & Soil \\
\hline Elbistan (ELB) & 38.203 & 37.202 & 212 & 4 & 5 & 5.6 & Soil \\
\hline
\end{tabular}

*Peak horizontal accelerations after the baseline correction and $0.25-25 \mathrm{~Hz}$ band pass filter.

Table 2. Modeling parameters for the June 27, 1998 Adana-Ceyhan earthquake.

\begin{tabular}{lc}
\hline Parameter & Parameter value \\
\hline Fault orientation (strike/dip) & $50^{\circ} / 85^{\circ}$ \\
Depth of upper edge of fault $(\mathrm{km})$ & 15 \\
Depth of hypocenter $(\mathrm{km})$ & $\sim 32$ \\
Fault dimensions $(\mathrm{km})$ & 30 by 21 \\
Subfault dimensions $(\mathrm{km})$ & 3 by 3 \\
Moment magnitude $\left(\mathrm{M}_{w}\right)$ & 6.3 \\
Stress parameters $(\mathrm{MPa})$ & 5 \\
Crustal shear wave velocity $(\mathrm{m} / \mathrm{s})$ & 3500 \\
Crustal density $\left(\mathrm{kg} / \mathrm{m}^{3}\right)$ & 2800 \\
Attenuation, $Q(f)$ & $88 f^{0.9}$ \\
Distance-dependent duration term $(\mathrm{s})$ & $0(\mathrm{R}<10 \mathrm{~km}), 0.16 \mathrm{R}(10<\mathrm{R}<70 \mathrm{~km})$ \\
& $-0.03 \mathrm{R}(70<\mathrm{R}<130 \mathrm{~km}), 0.04 \mathrm{R}(\mathrm{R}>130 \mathrm{~km})$ \\
Geometric spreading & $1 / \mathrm{R}$ \\
Kappa operator $(\kappa)$ & 0.035 \\
Windowing function & Saragoni-Hart \\
Radiation-strength factor & 1 \\
Crustal amplification & Generic rock site \\
Local amplification & Mean rock and soil amplification \\
\hline
\end{tabular}

spreading and attenuation $(Q)$ models. Contributions from all subfaults are lagged and summed at the receiver. Each subevent has an $\omega$-square spectrum. The ground motion at an observation point is obtained by summing the contributions over several subfaults. The number of subfault triggering is adjusted to conserve the total moment of the modeled earthquake with inhomogeneous slip distribution allowed on the target fault. Applicability of the method to ground motion prediction in various tectonic environments has been verified in several recent studies (Berardi et al., 2000; Atkinson and Beresnev, 2002; Erdik and Durukal, 2003; Roumelioti and Kiratzi, 2002; Roumelioti and Beresnev, 2003; Benetatos and Kiratzi, 2004). Further details and a complete description of the method are given by Beresnev and Atkinson (1997, 1998a).

The modeling parameters used for the simulations of the Adana-Ceyhan earthquake are given in Table 2. The mo- ment magnitude and fault mechanism was adopted from the work of Aktar et al. (2000). Depth of the mainshock is 32 $\mathrm{km}$, while the aftershocks have depths between $17 \mathrm{~km}$ and $37 \mathrm{~km}$ (Aktar et al., 2000). Based on the spatial distribution of the aftershocks (Aktar et al., 2000) and the lack of surface rupture, a rectangular fault with dimensions of 30 $\mathrm{km} \times 21 \mathrm{~km}$ and a depth of $15 \mathrm{~km}$ to the upper edge of the fault was assumed (Fig. 2). The fault plane was discretized into $3 \mathrm{~km} \times 3 \mathrm{~km}$ subfaults. This subfault size best adjusts the observations and fits the subfault dimension estimated from the relation of Beresnev and Atkinson (1999). The hypocenter was located at the bottom southwest corner of the fault plane, according to the proposed epicenter locations, suggesting unilateral rupture toward NE. No information was available regarding the slip distribution on the fault plane, so we adopted a random normally distributed slip. According to Beresnev and Atkinson (1998b), this choice 


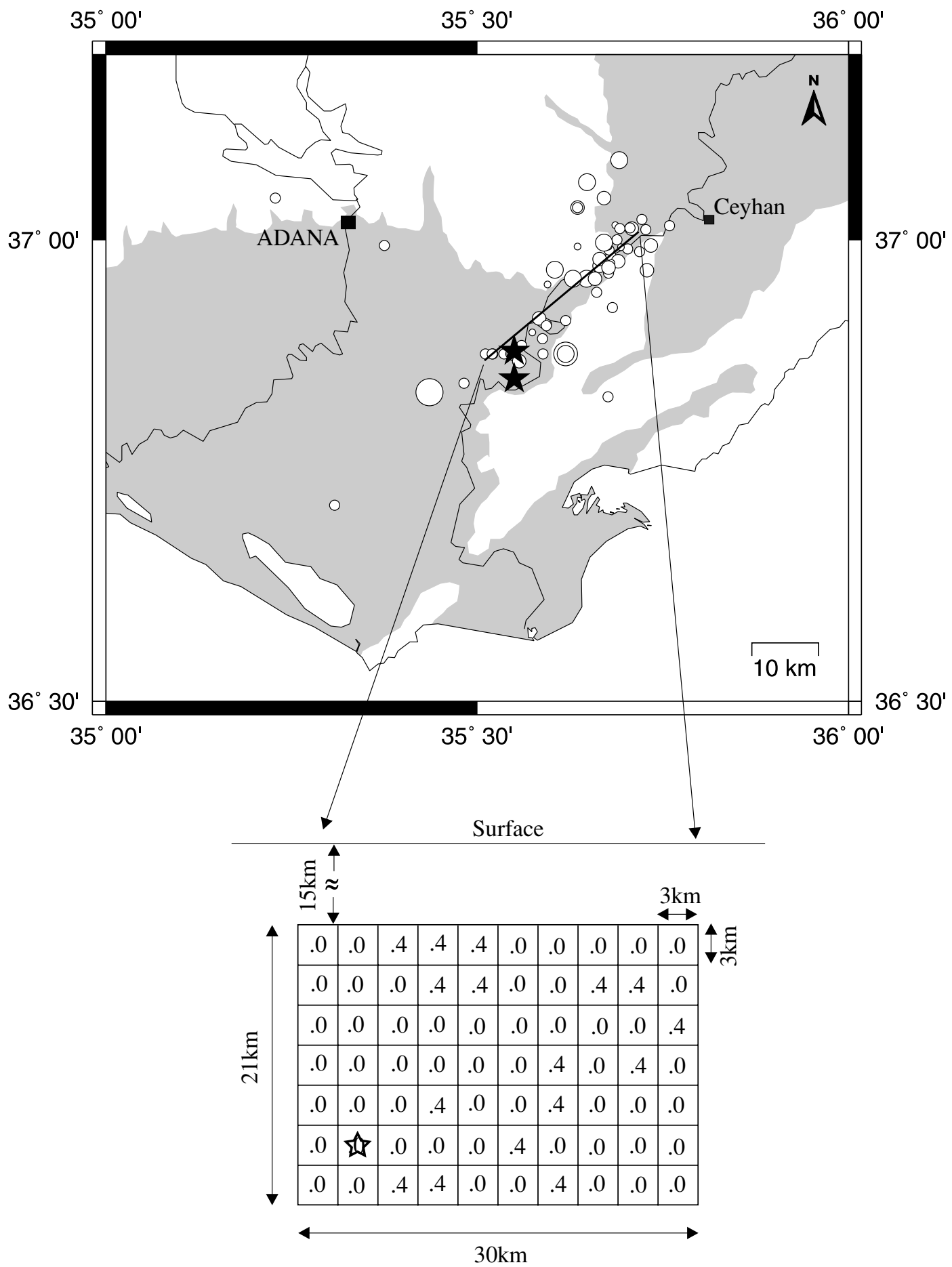

Fig. 2. Regional map showing the epicenters of aftershocks (circles: $2.2<\mathrm{M}<5.0$ ) and the mainshock (stars: the upper location from Aktar et al. (2000), and the bottom location from ERD) of the June 27, 1998 Adana-Ceyhan earthquake, along with the surface projection of the fault employed to model the earthquake. The gray area in the map shows Quaternary alluvium. The finite-fault model used in the simulations are shown at the bottom. The hypocenter is marked with the star. The numbers on subfaults indicate the resulting slip values in meters.

does not considerably affect the accuracy of predicting the average characteristics of ground motion, however, the directivity effects controlled by the hypocenter location are important in determining peak ground acceleration at individual sites. The radiation strength factor, which is the parameter controlling the level of high frequency radiation in the simulated spectra, was determined by trial and the best fit was obtained with 1.0, which corresponds to a standard rupture. The values adopted for the density, the shear wave velocity, and the stress drop are $2800 \mathrm{~kg} / \mathrm{m}^{3}, 3500 \mathrm{~m} / \mathrm{s}$, and $5 \mathrm{MPa}$, respectively, which are typical values for the region (Chen and Atkinson, 2002).

In the stochastic method, the attenuation effects of the propagation path are modeled through the empirical $Q$ and geometric spreading models. Because there is a lack of relevant studies on these topics in the region, we as- 

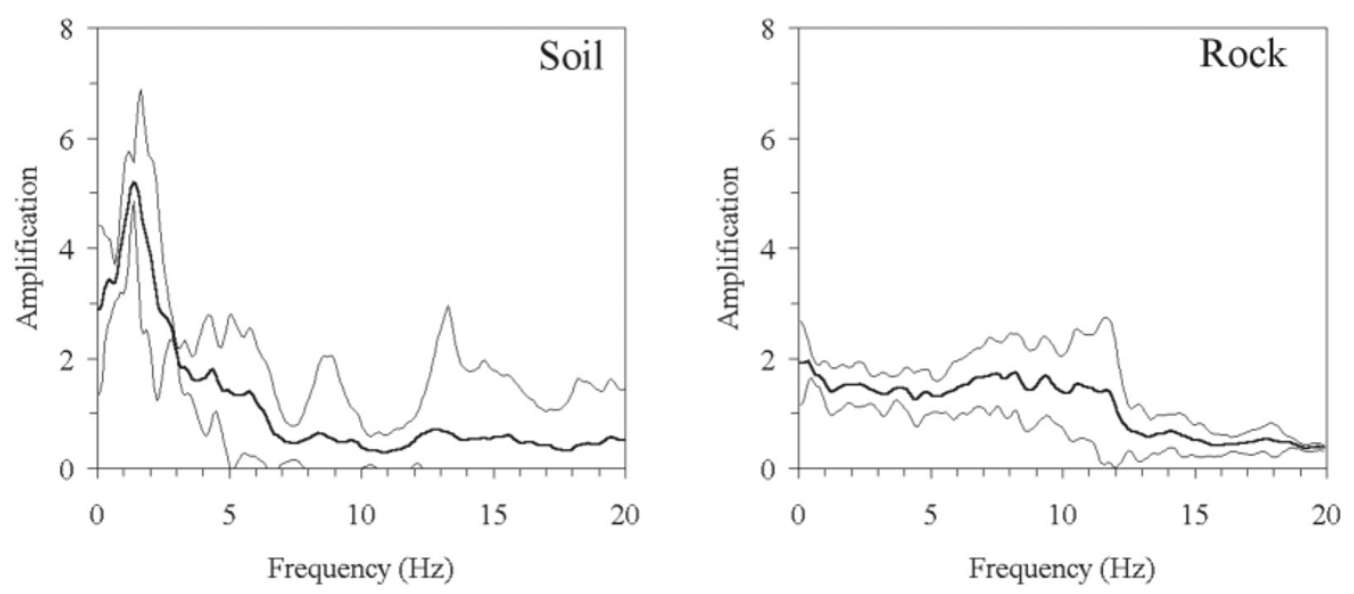

Fig. 3. The mean soil and rock amplification functions used for the local response of the station sites. The thin lines indicate plus and minus standard deviation.

sumed the frequency dependent $Q=88 f^{0.9}$, estimated by Boore (1984). This relation was successfully used for Turkey (Chen and Atkinson, 2002) and Greece (Margaris and Boore, 1998), and it is similar with the attenuation models obtained for Greece (Hatzidimitriou, 1995) and Turkey (Akinci et al., 1994; Horasan and Boztepe-Guney, 2004). For the geometric attenuation, we tested several geometric spreading terms, and the best fit was obtained with geometrical spreading in the form $1 / \mathrm{R}$. This form of geometrical spreading implies dominance of body waves in the used distance range. Generally, for earthquakes having shallow depths $(h<20 \mathrm{~km}) 1 / \mathrm{R}^{05}$ is used for geometrical spreading at epicentral distances larger than about 40 to $100 \mathrm{~km}$, due to dominance of surface waves (e.g. Beresnev and Atkinson, 2002; Singh et al., 2003). However, Atkinson (1995) suggested a simple 1/R attenuation curve over all epicentral distance ranges for lower crust earthquakes $(h>20$ $\mathrm{km}$ ), because deeper events may set up quite different wave trains, and surface waves may not be excited. The AdanaCeyhan is a lower crust earthquake, however, the surface waves are clear especially at distant stations (KMR, GOL, ELB). In that case, the anelestic attenuation term may be lower than the used (i.e. higher attenuation), because high attenuation is suggested for lower crust due to increasing temperature (Mitchell, 1995). This dilemma between the anelastic attenuation and the geometrical spreading terms needs further study, however, it does not affect our results. For the duration, we could not make a detailed check, because the record durations were inappropriate to compare at most stations.

The crustal response was accommodated by amplifying the simulated spectra by the factors proposed for generic rock sites in western North America (Boore and Joyner, 1997). The spectra were additionally attenuated by the kappa operator with $\kappa=0.035 \mathrm{~s}$ (Margaris and Boore, 1998), which controls the path-independent high-frequency decay of the spectrum (Anderson and Hough, 1984). For the local response, the mean soil and rock amplification functions is used. Yalcinkaya and Alptekin (2005a) estimated site-specific amplification functions from the weakmotion recordings at 15 stations located in the Adana-
Ceyhan region. It is considered that the geologic characteristics underlying their stations display similarities with those of our stations, because all stations are located in the same tectonic area, albeit even if their locations are different. For the mean soil amplification function used in this study, we averaged Yalcinkaya and Alptekin (2005a)'s amplification functions estimated for the soil stations using the Standard Spectral Ratio method (Borcherdt, 1970), and for the mean rock amplification function used in this study we averaged Yalcinkaya and Alptekin (2005a)'s amplification functions estimated for the rock or stiff soil stations using the Horizontal-to-Vertical Spectral Ratio method (Nakamura, 1989; Lermo and Chavez-Garcia, 1993). Even if the discussions about the accuracy of results of the Horizontalto-Vertical Spectral Ratio method continue; that is, it usually underestimates true amplifications (e.g. Yalcinkaya and Alptekin, 2005a), we were forced to use the results of this method for the mean rock amplification function, because it was impossible to define the best rock station for reference. The mean soil and rock amplification functions and their standard deviations derived for this study are presented in Fig. 3. Important amplifications for the soil sites are up to $6 \mathrm{~Hz}$. At the higher frequencies for soil sites the attenuation is more effective on the amplitudes and causes negative amplification. Generally, amplifications in simulations of rock sites are assumed 1. However, it is hard to accept the rock sites simulated in this study as "hard rock". At such sites, the seismic motions are amplified due to the presence of fractured structure and thin weathered layers. As seen in Fig. 3, the amplification values for the rock sites are about $1.5 \mathrm{up}$ to $12 \mathrm{~Hz}$, and at higher frequencies the values change into deamplification due to high near surface attenuation.

It is now well accepted that soils behave nonlinearly when subjected to strong levels of ground shaking (Beresnev and Wen, 1996). The effect of nonlinearity is to reduce the amount of amplification as the input ground motion level is increased. Since Yalcinkaya and Alptekin (2005a)'s amplification functions were calculated from the weak motion records, they may not be extended for strong motions. Unfortunately, we do not know the nonlinear characteristics of the soil sites used in this study, therefore, the uncertainty 

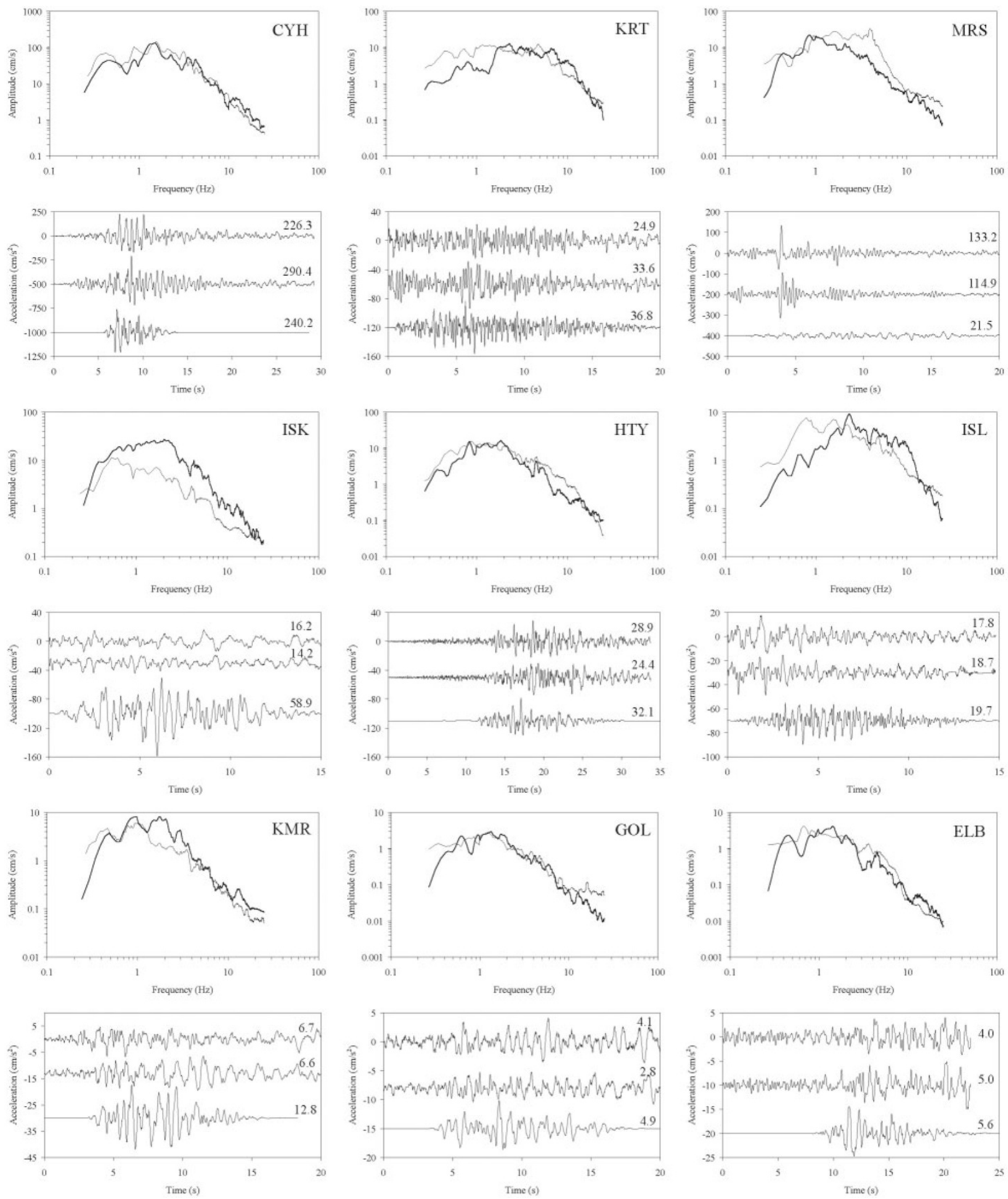

Fig. 4. The observed and simulated accelerograms and Fourier amplitude spectra of the June 27, Adana-Ceyhan earthquake. The observed and simulated spectra, which are smoothed a moving window, are shown by thin and thick lines, respectively. The two upper traces below each spectrum are the observed horizontal accelerations. The third trace below each spectrum is the simulated random horizontal component which has a sampling interval equal to that of the original recorded traces. The peak ground acceleration in $\mathrm{cm} / \mathrm{s}^{2}$ is shown above each trace.

arose from the nonlinearity may be important especially at high frequencies (Atkinson and Beresnev, 2002), and at the near-source stations, which have high input ground motion levels $\left(>\sim 2.0 \mathrm{~m} / \mathrm{s}^{2}\right)$, for example at the CYH station.

An additional uncertainty that has not been considered is potential basin effects (Hruby and Beresnev, 2003). Surface waves generated from basin edges increase amplitudes and durations of ground motions recorded within basin (e.g. Joyner, 2000; Yalcinkaya and Alptekin, 2005b). The effects of surface waves change relative to the location of recording station depending on the basin geometry. Therefore, the simulations at the stations located within the basin may not perfectly match with the observed records in amplitude and duration. 


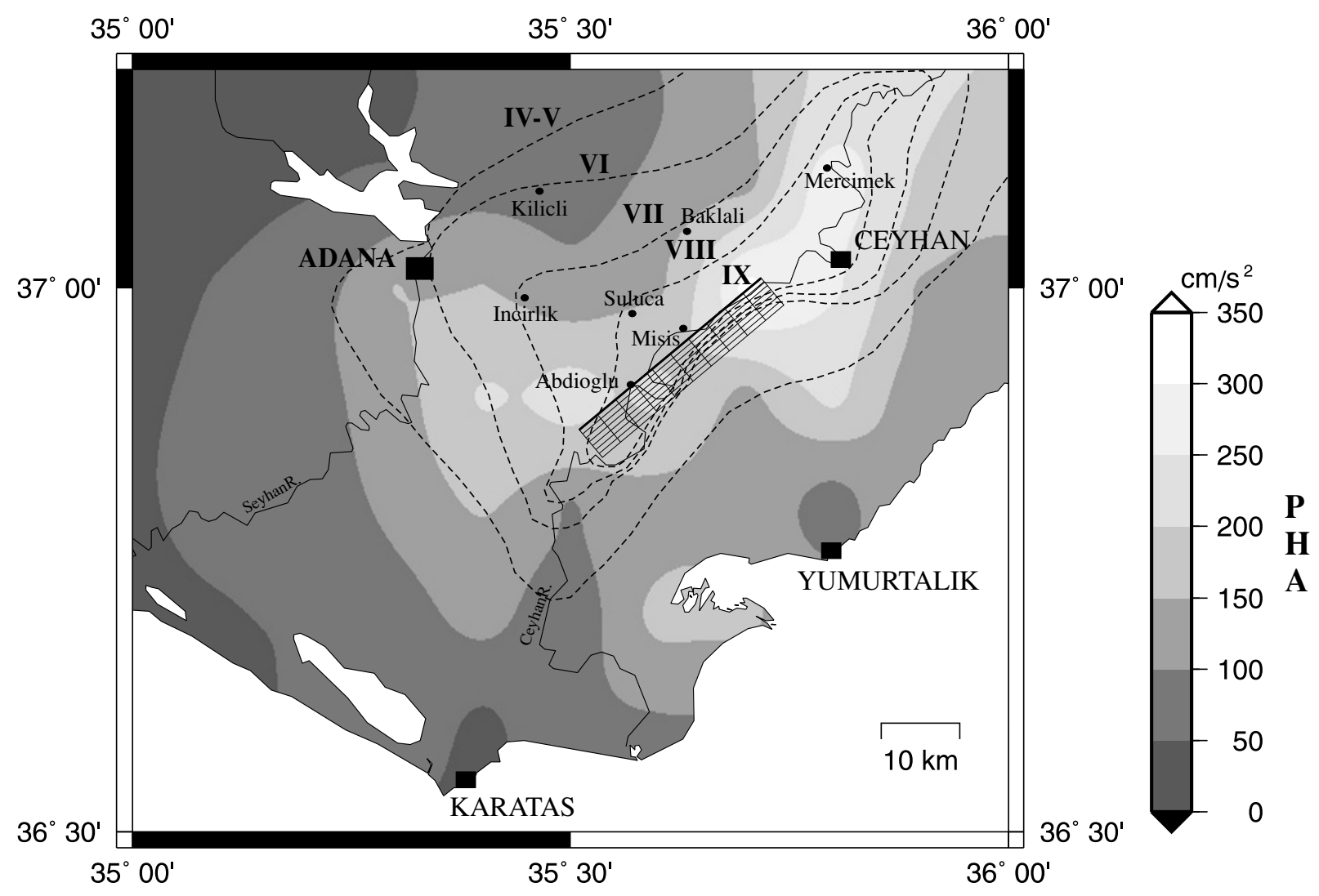

Fig. 5. Comparison of the simulated peak horizontal accelerations (PHA: the gray scale) with the macroseismic intensity contours (the dashed contours scaled by roman numbers) reported by Cetin and Demirtas (1998) for the Adana-Ceyhan earthquake. The surface projection of the fault plane used for the simulations also shown in the figure.

\section{Results and Discussions}

Figure 4 compares the Fourier amplitude spectra as well as the recorded and simulated accelerograms at the station sites. Taking into account the suitability of the used parameters, the overall agreement between the simulated and observed seismograms is very satisfactory both in the time and frequency domains. The largest misfit is observed at MRS, ISK and KMR stations. Peak ground accelerations are approximately underestimated more than a factor of 6 at MRS, and overestimated a factor of 3 and 2 at ISK and KMR, respectively. In addition to these stations, little discrepancies are observed between the simulated and observed spectra of KRT and ISL stations at low frequencies $(>2 \mathrm{~Hz})$. The reason for these discrepancies cannot be the effect of nonlinearity, because the input ground motions at these stations are not sufficiently high for nonlinear soil behavior. The MRS, ISK and KMR stations are located at different distances and azimuths relative to the epicenter, therefore, the attenuation models we use can not be the reason for misfits. The misfits may arise from the inadequate representation of the local site amplifications by the mean amplification functions, because the used source model works well at other stations. Also, the abnormal high peak and the incomplete record observed on the records of MRS and ISK, respectively, may have been arisen from the performance of the accelerographs or the building-soil interaction. At the $\mathrm{CYH}$ station net effects of nonlinearity and surface waves are expected, however, the results are satisfactory, although the duration of simulated record is shorter than those of the ob- served records. The reason for longer durations of observed records is probably due to the surface waves generated from basin edges.

After the method is calibrated for the data recorded at 9 sites, we used the calibrated model to simulate acceleration values at other sites to compare with the observed damage within the Adana-Ceyhan region. For this purpose, we divided the region shown in Fig. 5 into grid points spaced $0.1^{\circ}(\sim 10 \mathrm{~km})$ and simulated the acceleration record at each grid point. The site classification (rock or soil) for each point was made from the geologic map of Turkey with a scale 1:500,000 (MTA, 2002). The most of the region is covered by Quaternary alluvium (the gray area in Fig. 2). The points located within the alluvium were classified as soil, while the points located at other units (Travertine, Pliocene, Miocene and Eocene) were classified as rock.

It is known that the ground motion in the near-fault region is greatly affected by the complexity in the slip distribution and rupture propagation. We use random normally distributed fault slip for the Adana-Ceyhan earthquake (Fig. 2), therefore, this may cause some uncertainties on the nearfield ground motions. According to Beresnev and Atkinson (1998b), using the random slip models does not lead to any appreciable decrease in accuracy of prediction of the mean nor does it increase the standard deviation, as compared to the actual slip derived from recorded geophysical data. However, the accelerations at individual points will vary, due to directivity effects controlled by the rupture propaga- 
tion and the slip direction (Somerville, 2003). Beresnev and Atkinson (1997) simulated the ground motions using 10 different randomly distributed slip values. They calculated that the maximum uncertainty was $33 \%$ for spectral amplitudes and $11 \%$ for peak ground acceleration. Singh et al. (2003) stated that the ground motions estimated with a prescribed slip distribution were $10 \%-15 \%$ higher than in the case of randomly generated slip. We think that the uncertainty from the rupture directivity might be small in this study comparing to the effect of the random slip distribution, because the location of the hypocenter is well constrained.

The contours of peak horizontal acceleration (PHA) obtained from simulation are shown with gray scale in Fig. 5. In addition, the intensity contours of the 27 June 1998 Adana-Ceyhan earthquake (Cetin and Demirtas, 1998) are shown with the dashed lines in Fig. 5 for comparison. The simulated PHAs are consistent with the intensity observations. The model we used for simulations suggests a rupture propagation toward the northeast, because the rupture starting point is at the bottom southwest corner of the fault plane (Fig. 2). Therefore, strong forward directivity effects occur toward the northeastern end of the fault. The maximum PHA value $\left(3.27 \mathrm{~m} / \mathrm{s}^{2}\right)$ is calculated in that area. The forward directivity causes high accelerations in Ceyhan town $\left(2.5<\mathrm{PHA}<3.0 \mathrm{~m} / \mathrm{s}^{2}\right)$, which was severely damaged during the earthquake. The model predicts PHA of about $2.0 \mathrm{~m} / \mathrm{s}^{2}$ in Suluca and Misis towns that damaged extensively, and about $2.5 \mathrm{~m} / \mathrm{s}^{2}$ in Abdioglu, which is accepted as macroseismic epicenter due to extensive ground failures. Widespread liquefaction and lateral spreading of the ground were observed for a distance of $50 \mathrm{~km}$, from Abdioglu to Mercimek, particularly along the banks of the Ceyhan River (Adalier and Aydingun, 2000; Ulusay et al., 2000). These observations are consistent with the high accelerations simulated for the same areas. Predicted PHA values are about 1.0-1.5 $\mathrm{m} / \mathrm{s}^{2}$ in Adana city, which is exposed to minor damage.

\section{Conclusion}

In this study, the acceleration time histories and Fourier amplitude spectra of the June 27, 1998 Adana-Ceyhan earthquake were simulated using the stochastic finite-fault method. A rectangular rupture area of $30 \mathrm{~km} \times 21 \mathrm{~km}$ with the top at $15 \mathrm{~km}$, based on the aftershock distribution, was assumed. The mean amplification functions estimated for rock and soil sites using the spectral ratio methods to account for the local site response were used. Although significant discrepancies are observed at certain stations, the results show a satisfactory match between simulated and observed acceleration time histories and spectra. The discrepancies could be due to inadequate representation of the local site amplifications by the mean amplification functions. The effects of nonlinearity and surface waves were not observed dominantly in the simulations, because only $\mathrm{CYH}$ station was located in the basin and the ground motion at this station was sufficiently high for nonlinearity. The PHAs computed using the calibrated stochastic model are in accordance with the intensity values, damage, widespread liquefaction and lateral spreading caused by the strong ground motions during the Adana-Ceyhan earthquake. Strong forward directivity effects were observed toward the town of
Ceyhan, which is damaged extensively during the earthquake.

In conclusion, the stochastic finite-fault modeling confirms the view proposed by Aktar et al. (2000), that the June 27, 1998 Adana-Ceyhan earthquake nucleated within the lower crust, and did not extend to shallower zones. Although there is a lack of relevant studies in the region, the generic parameters used for the simulations are quite successful, and can be used for predicting ground motions from future earthquakes in the region. The results of this study have shown that the stochastic modeling is very useful to explain the occurred damages for earthquakes, which have rare records. For more convenient modeling, the sitespecific amplification studies are very important.

Acknowledgments. Thanks are due to Prof. Igor Beresnev for kindly helping and offering the simulation code, FINSIM. The author is grateful to the referees T. Kagawa and H. Miyake, and the associate editor E. Fukuyama for their valuable comments and suggestions. Special thanks to Omer Alptekin and Murat Utkucu for helps that improved the manuscript.

\section{References}

Adalier, K. and O. Aydingun, Liquefaction during the June 27, 1998 Adana-Ceyhan (Turkey) earthquake, Geotechnical and Geological Engineering, 18, 155-174, 2000.

Adalier, K. and O. Aydingun, Structural engineering aspects of the June 27, 1998 Adana-Ceyhan (Turkey) earthquake, Engineering Structures, 23, 343-355, 2001.

Akinci, A., A. G. Taktak, and S. Ergintav, Attenuation of coda waves in Western Anatolia, Phys. Earth Planet. Inter., 87, 155-165, 1994.

Aktar, M., M. Ergin, S. Ozalaybey, C. Tapıdamaz, A. Yoruk, and F. Bicmen, A lower-crustal event in the Northeastern Mediterranean: The 1998 Adana earthquake $(\mathrm{Mw}=6.2)$ and its aftershocks, Geophys. Res. Lett., 27, 2361-2364, 2000.

Anderson, J. G. and S. E. Hough, A model for the shape of the Fourier spectrum of acceleration at high frequencies, Bull. Seism. Soc. Am., 74, 1969-1993, 1984.

Atkinson, G. M., Attenuation and source parameters of earthquakes in the Cascadia region, Bull. Seism. Soc. Am., 85, 1327-1342, 1995.

Atkinson, G. M. and I. A. Beresnev, Ground motions at Memphis and St. Louis from M 7.5-8.0 earthquakes in the New Madrid Seismic Zone, Bull. Seism. Soc. Am., 92, 1015-1024, 2002.

Atkinson, G. M. and D. M. Boore, Stochastic point-source modeling of ground motions in the Cascadia region, Seism. Res. Lett., 68, 74-85, 1997.

Barka, A., S. Akyuz, and E. Altunel, Active Tectonics of the Adana Region and The 1998 Adana Earthquake, Aktif Tektonik-2, edited by A. Barka, S. Akyuz, and E. Altunel, TDV, 20-31, 1998 (in Turkish with English abstract).

Benetatos, C. A. and A. A. Kiratzi, Stochastic strong ground motion simulation of intermediate depth earthquakes: the cases of the 30 May 1990 Vrancea (Romania) and of the 22 January 2002 Karpathos island (Greece) earthquakes, Soil Dyn. Earthquake Eng., 24, 1-9, 2004.

Berardi, R., M. J. Jimenez, G. Zonno, and M. Garcia-Fernandez, Calibration of stochastic finite-fault ground motion simulations for the 1997 Umbria-Marche, Central Italy, earthquake sequence, Soil Dyn. Earthquake Eng., 20, 315-324, 2000.

Beresnev, I. A. and G. M. Atkinson, Modeling finite-fault radiation from the $\omega^{n}$ spectrum, Bull. Seism. Soc. Am., 87, 67-84, 1997.

Beresnev, I. A. and G. M. Atkinson, FINSIM: a FORTRAN program for simulating stochastic acceleration time histories from finite faults, Seism. Res. Lett., 69, 27-32, 1998a.

Beresnev I. A. and G. M. Atkinson, Stochastic finite-fault modeling of ground motions from the 1994 Northridge, California, earthquake. I. Validation on rock sites, Bull. Seism. Soc. Am., 88, 1392-1401, 1998b.

Beresnev, I. A. and G. M. Atkinson, Generic finite-fault model for ground motion prediction in eastern North America, Bull. Seism. Soc. Am., 89, 608-625, 1999.

Beresnev, I. A. and G. M. Atkinson, Source parameters of earthquakes in Eastern and Western North America based on finite-fault modeling, 
Bull. Seism. Soc. Am., 92, 695-710, 2002.

Beresnev, I. A. and K.-L. Wen, Nonlinear soil response: a reality?, Bull. Seism. Soc. Am., 86, 1964-1978, 1996.

Boore, D. M., Stochastic simulation of high-frequency ground motions based on seismological models of the radiated spectra, Bull. Seism. Soc. Am., 73, 1865-1894, 1983.

Boore, D. M., Use of seismoscope records to determine ML and peak velocities, Bull. Seism. Soc. Am., 74, 315-324, 1984.

Boore, D. M., SMSIM-Fortran programs for simulating ground motions from earthquakes: version 1.0, U.S. Geol. Surv. Open-File Rept., 9680-A, 73 pp, 1996.

Boore, D. M. and G. M. Atkinson, Stochastic prediction of ground motion and spectral response parameters at hard-rock sites in eastern North America, Bull. Seism. Soc. Am., 77, 440-467, 1987.

Boore, D. M. and W. Joyner, Site amplification for generic rock sites, Bull. Seism. Soc. Am., 87, 327-341, 1997.

Boore, D. M., W. Joyner, and T. Fumal, Estimation of response spectra and peak acceleration from Western North American earthquakes: an interim report, U.S. Geol. Surv. Open-File Rept., 93-509, 1993.

Borcherdt, R. D., Effects of local geology on ground motion near San Francisco Bay, Bull. Seism. Soc. Am., 60, 29-61, 1970.

Celebi, M., Revelations from a single strong-motion record retrieved during the 27 June 1998 Adana (Turkey) earthquake, Soil Dyn. Earthquake Eng., 20, 283-288, 2000.

Cetin, H. and R. Demirtas, Jeolojik ve topografik faktorlerin 27 Haziran, 1998 Adana depremi hasar dagılımı uzerindeki etkisi, Kentlesme ve Jeoloji Sempozyumu, Avcilar Belediye Baskanlıgı, 141-150, 1998 (in Turkish).

Chen, S. and G. M. Atkinson, Global comparisons of earthquake source spectra, Bull. Seism. Soc. Am., 92, 885-895, 2002.

Erdik, M. and E. Durukal, Simulation modeling of strong ground motion, in Earthquake Engineering Handbook, edited by W. F. Chen and C. Scawthorn, CRC Press, Boca Raton, Florida, 6-16-67, 2003.

Joyner, W., Strong motion from surface waves in deep sedimentary basins, Bull. Seism. Soc. Am., 90, S95-S112, 2000.

Hanks, T. C. and R. K. McGuire, The character of high-frequency strong ground motion, Bull. Seism. Soc. Am., 71, 2071-2095, 1981.

Hatzidimitriou, P. M., S-wave attenuation in the crust in northern Greece, Bull. Seism. Soc. Am., 85, 1381-1387, 1995.

Horasan, G. and A. Boztepe-Guney, S-wave attenuation in the Sea of Marmara, Turkey, Phys. Earth Planet. Inter., 142, 215-224, 2004.

Hruby, C. E. and I. A. Beresnev, Empirical corrections for basin effects in stochastic ground-motion prediction, based on the Los Angles basin analysis, Bull. Seism. Soc. Am., 93, 1679-1690, 2003.

Kamae, K. and K. Irikura, Prediction of site-specific strong ground motion using semiempirical methods, in Proc. of the Tenth World Conference on Earthquake Engineering, Madrid, Spain, 19-24 July 1992, 801-806.

Kozlu, H., Stratigraphy and structural evolution of Misis-Andirin region,
Turkish 7th Petroleum Congress, 1987 (in Turkish with English abstract).

Lermo, J. and F. J. Chavez-Garcia, Site effect evaluation using spectral ratios with only one station, Bull. Seism. Soc. Am., 83, 1574-1594, 1993.

Margaris, B. N. and D. M. Boore, Determination of $\Delta \sigma$ and $\kappa_{0}$ from response spectra of large earthquakes in Greece, Bull. Seism. Soc. Am., 88, 170-182, 1998.

Mitchell, B. J., Anelastic structure and evolution of the continental crust and upper mantle from seismic wave attenuation, Rev. Geophys., 33, 441-462, 1995.

MTA, 1:500.000 scale geological maps of Turkey, No: 15, General Directorate of Mineral Research and Exploration, 2002.

Nakamura, Y., A method for dynamic characteristics estimation of subsurface using microtremor on the ground surface, QR Railway Tech. Res. Inst., 30, 25-33, 1989.

Roumelioti, Z. and I. A. Beresnev, Stochastic finite-fault modeling of ground motions from the 1999 Chi-Chi, Taiwan, earthquake: application to rock and soil sites with implications for nonlinear site response, Bull. Seism. Soc. Am., 93, 1691-1702, 2003.

Roumelioti, Z. and A. A. Kiratzi, Stochastic simulation of strong-motion records from the 15 April 1979 (M 7.1) Montenegro earthquake, Bull. Seism. Soc. Am., 92, 1095-1101, 2002.

Singh, S. K., B. K. Bansal, S. N. Bhattacharya, J. F. Pacheco, R. S. Dattatrayam, M. Ordaz, G. Suresh, Kamal, and S. E. Hough, Estimation of ground motion for Bhuj (26 January 2001; Mw 7.6) and for future earthquakes in India, Bull. Seism. Soc. Am., 93, 353-370, 2003.

Somerville, P. G., Magnitude scaling of the near fault rupture directivity pulse, Phys. Earth Planet. Inter., 137, 201-212, 2003.

Toro, G. R., N. A. Abrahamson, and J. F. Schneider, Model of strong ground motions from earthquakes in central and eastern North America: best estimates and uncertainties, Seism. Res. Lett., 68, 41-57, 1997.

Ulusay, R., O. Aydan, H. Kumsar, and H. Sonmez, Engineering geological characteristics of the 1998 Adana-Ceyhan earthquake, with particular emphasis on liquefaction phenomena and the role of soil behaviour, Bull. Eng. Geol. Env., 59, 99-118, 2000.

Utkucu, M., A. Pinar, and O. Alptekin, Finite-source modelling of the June 27, 1998, Adana, Turkey earthquake $(\mathrm{Mw}=6.4)$ from broadband teleseismic P and SH waveforms, EOS, Trans. Am. Geophys. Un., Fall Meet. Suppl., 82, F973, 2001.

Yalcinkaya, E. and O. Alptekin, Site effect and its relationship with the intensity and damage observed in the June 27, 1998 Adana-Ceyhan earthquake, Pageoph, 2005a (in print).

Yalcinkaya, E. and O. Alptekin, Contributions of the basin edge induced surface waves to site effect in the Dinar basin, Southwestern Turkey, Pageoph, 2005b (in print).

E. Yalcinkaya (e-mail: eyalcin@istanbul.edu.tr) 